\title{
A life cycle assessment of the construction phase of eleven micro- hydropower installations in the UK
}

Ueda, T.; Roberts, E.S.; Styles, David; Williams, Arwel; Ramos, H.M.; Gallagher, John

\section{Journal of Cleaner Production}

DOI:

10.1016/j.jclepro.2019.01.267

Published: 01/05/2019

Peer reviewed version

Cyswllt i'r cyhoeddiad / Link to publication

Dyfyniad o'r fersiwn a gyhoeddwyd / Citation for published version (APA):

Ueda, T., Roberts, E. S., Styles, D., Williams, A., Ramos, H. M., \& Gallagher, J. (2019). A life cycle assessment of the construction phase of eleven micro-hydropower installations in the UK. Journal of Cleaner Production, 218, 1-9. https://doi.org/10.1016/j.jclepro.2019.01.267

\section{Hawliau Cyffredinol / General rights}

Copyright and moral rights for the publications made accessible in the public portal are retained by the authors and/or other copyright owners and it is a condition of accessing publications that users recognise and abide by the legal requirements associated with these rights.

- Users may download and print one copy of any publication from the public portal for the purpose of private study or research.

- You may not further distribute the material or use it for any profit-making activity or commercial gain

- You may freely distribute the URL identifying the publication in the public portal ?

Take down policy

If you believe that this document breaches copyright please contact us providing details, and we will remove access to the work immediately and investigate your claim. 


\title{
A LIFE CYCLE ASSESSMENT OF THE CONSTRUCTION PHASE OF ELEVEN MICRO-HYDROPOWER INSTALLATIONS IN THE UK
}

\author{
T. Uedaa , E.S. Roberts ${ }^{b}$, A. Norton ${ }^{c, d}$, D. Styles ${ }^{d, e}$, A.P. Williams ${ }^{d}$, H.M. Ramos ${ }^{f}$, J. Gallagher ${ }^{d, g, *}$ \\ a Dept. of Energy Engineering and Management, Instituto Superior Técnico, University of Lisbon, Lisbon, Portugal \\ ${ }^{b}$ Graduate School of the Environment, Centre for Alternative Technology, Machynlleth, Powys, Wales, United Kingdom \\ ${ }^{\mathrm{c}}$ Renuables, 41 High Street, Menai Bridge, Isle of Anglesey, Wales, United Kingdom \\ d School of Natural Sciences, Bangor University, Wales, United Kingdom \\ e Plant and Agri-biosciences Centre, Ryan Institute, NUI Galway, Galway, Ireland \\ ${ }^{f}$ Dept. of Civil Engineering, Architecture \& Georesources, Instituto Superior Técnico, University of Lisbon, Lisbon, Portugal \\ g Dept. of Civil, Structural \& Environmental Engineering, Trinity College Dublin, The University of Dublin, Dublin, Ireland \\ * Corresponding author. Tel: (+353) 18961638 \\ Email address: j.gallagher@tcd.ie
}

\begin{abstract}
The rapid deployment of renewable energy technologies continues, yet the environmental impacts associated with their construction is accepted without sustainable design considerations. This life cycle assessment study quantifies the embodied burdens in the construction phase of eleven microhydropower installations, ranging from 70 to $100 \mathrm{~kW}$ in size. The consumption of concrete and aggregates, metals and plastics influence each of the five impact categories assessment differently. In relation to global warming potential, upstream production of concrete and aggregates contributed $25-44 \%$, whilst production of plastics contributed $27-49 \%$. For acidification potential, production of metals and plastics contributed $29-67 \%$ and $19-45 \%$, respectively. Production of metals used in MHP projects contributed 86 $98 \%$ of human toxicity potential and $79-98 \%$ of abiotic resource depletion, whilst production of plastics contributed $56-77 \%$ of fossil resource depletion potential. One low-head scheme had the highest global warming, acidification and fossil resource depletion burdens due to large quantities of materials used in construction, while another scheme demonstrated high human toxicity and abiotic resource depletion burdens due to a 3-kilometre grid connection upgrade for exporting electricity. The results were more sensitive to the quantity of materials used in the micro-hydropower projects than to changes in transport and construction contributions. The use of alternative materials could reduce global warming potential, e.g. a wood-frame powerhouse instead of concrete construction would reduce it by $6-12 \%$. The results also indicated a general trend of reduced burdens per kWh electricity generated as capacity increased. However, no clear correlations were found between site-specific characteristics and environmental
\end{abstract}


impacts in constructing these micro-hydropower projects. Therefore, independent life cycle assessment case studies are still required to inform better construction practices for specific renewable energy projects, with significant potential to improve environmental performance, especially in relation to resource efficiency as per circular economy principles.

Keywords: renewable energy technology; embodied burdens; material selection; grid connection; head and flow characteristics.

\section{INTRODUCTION}

With continued economic and population growth globally, a dependency on fossil fuel energy sources gives rise to a continuation of greenhouse gases (GHGs) emissions and contributing to the adverse effects of climate change (REN21, 2016). In response, there has been significant growth in the renewable energy (RE) sector to reduce GHG emissions and to support a transition towards a low-carbon economy (IRENA, 2016). This has been boosted through significant government investment programmes (DECC, 2013), which has presented positive economic opportunities (US DOE, 2017).

Among the different RE systems, hydropower (HP) is considered the most mature and proven technology (IRENA, 2012). Globally, an estimated $31.5 \mathrm{GW}$ of new hydropower capacity was added around the world in 2016, with a total generation of 4,102 TWh, the largest output of all RE sources (IHA, 2017). The outlook for HP is continued growth, increasing the existing $14 \%$ energy share to a $20 \%$ contribution of global RE use by 2030 (IRENA, 2016). Whilst this growth has positive outcomes in terms of GHG mitigation through fossil energy displacement, it is heavily dependent on the use of finite material resources owing to comparatively large quantities of equipment and infrastructure per kWh electricity generated by RE technologies (Gallagher et al., 2015a, Gallagher et al., 2015c). This should be considered in the deployment of new RE projects, in line with the concepts of the circular economy and sustainability (Gallagher et al., 2018a).

Unlike fossil-fuel based energy generation, RE technology does not emit GHG emissions during its operation. However, there are environmental impacts associated with the manufacturing of turbine components and the construction of the RE installation (Gallagher et al., 2018a, Pehnt, 2006, Asdrubali et al., 2015). For example, the requirement for various durable materials to construct these HP systems leads to depletion of natural resources, as well as the fossil fuel consumption in the manufacturing and processing of system components.

Recent environmental assessments of HP installations have considered different forms of analysis, 
from embodied energy or emergy flows (Zhang et al., 2016, Tassinari et al., 2016), to water footprints (Bakken et al., 2016, Coelho et al., 2017) and carbon footprints (Zhang et al., 2015, Zhang and Xu, 2015). The findings from these studies are limited to specific environmental burdens and thus restrict the overall conclusions that can be drawn from the results. Therefore, to develop more sustainable HP plants, the ability to quantify and analyse the material flows through an environmental impact assessment (EIA) can assist in the adoption of low-carbon and resource efficient designs. Life cycle assessment (LCA) is a widely accepted systematic method that allows for the evaluation of numerous potential environmental impacts associated with delivery of a product or service throughout its entire life cycle (ISO, 2006a).

One example of an early and comprehensive LCA of three 'run-of-river' HP schemes in India, ranging in size from $50 \mathrm{~kW}$ to 3,000 kW, was Varun et al. (2008), which quantified the installation and operational and maintenance (O\&M) life cycle stage GHG emissions of these projects. The study outlined the contribution of GHG emissions (as global warming potential (GWP)) for the evaluated HP plants, with results ranging from 35 to 75 grams of carbon dioxide equivalent per kilowatt-hour ( $\mathrm{g} \mathrm{CO}_{2}$ eq./kWh) over the expected 30-year project lifespan. It presented the environmental impacts during the different life cycle stages for the HP plants, and demonstrated that larger capacity HP installations had a lower GWP burden per kWh of generation. Subsequent LCA studies reinforced the impact of scale on GHG emission results, with a value as low as $1.2 \mathrm{~g} \mathrm{CO}_{2}$ eq./kWh for a large $8 \mathrm{MW}$ installation (Hanafi and Riman, 2015) and higher results of $52.7 \mathrm{~g} \mathrm{CO}_{2}$ eq./kWh for a $3 \mathrm{~kW}$ pico-hydro installation (Pascale et al., 2011) notwithstanding possible influence of different LCA methodologies on these results.

More recent LCA studies of HP plants have evaluated a wider range of environmental impact categories (Gallagher et al., 2015a, Pascale et al., 2011, Suwanit and Gheewala, 2011, Hanafi and Riman, 2015). Although the number of impact categories presented differs across studies, each study included global warming potential (GWP), acidification potential (AP), abiotic resource depletion potential (ARDP), and human toxicity potential (HTP) in their life cycle impact assessments (LCIA). Furthermore, Pascale et al. (2011) assessed the additional environmental impact categories of ozone layer depletion potential (ODP), eutrophication potential (EP) and photochemical ozone creation potential (POCP), while Gallagher et al. (2015a), Hanafi and Riman (2015) and Suwanit and Gheewala (2011) also assessed the fossil resource depletion potential (FRDP) burden.

The most common environmental impact category presented in LCA studies is GWP, representing the carbon footprint of a project, and this typically can be the sole focus of the results in a study (e.g. Zhang et al., 2016). However, it is important to recognise the value of results for other specific burdens as this offers a broader perspective on the overall performance of run-of-river HP installations, in particular the 
sustainability of RE technology design and construction. For example, Hanafi and Riman (2015) and Suwanit and Gheewala (2011) identified steel, which was used in the penstock and pipes, as the main contributor to marine aquatic ecotoxicity potential (MAETP) and HTP, respectively. Thus, an inclusion of multiple impact categories can improve the understanding of potentially important wider environmental impacts and associated hotspots, providing a stronger evidence base to improve the sustainability of runof-river HP project design.

To date, the majority of previous LCA studies conducted on run-of-river schemes are mini- to mediumscale installations of between $100 \mathrm{~kW}-100 \mathrm{MW}$, and analysis was typically restricted to the GWP burden (Donnelly et al., 2010, Rule et al., 2009, Premalatha et al., 2014). A limited number of investigations have examined the environmental impacts of micro-hydropower (MHP) projects, at a scale of $5-100 \mathrm{~kW}$ (Gallagher et al., 2015a, Varun et al., 2008). Given the growth and potential of MHP projects (Gallagher et al., 2018b, Bódis et al., 2014), this assessment is needed. This study presents a detailed account of LCA results in the construction of eleven individual MHP projects of a similar size (70-100 kW). This provides an opportunity to examine environmental impact variations associated with design and construction details for multiple MHP projects of the same scale, following the same precise methodology and capturing detailed information relating to their installation.

\section{METHODS}

\subsection{Goal and Scope}

This study applies LCA methodology to quantify the environmental impacts associated with the construction phase of a selection of MHP installations that vary in their design and construction. The LCA has been conducted in accordance with ISO 14040 and 14044 guidelines (ISO, 2006a, 2006b). The functional unit selected for this study was $1 \mathrm{kWh}$ electricity generated. This has been used by previous LCA studies of run-of-river HP schemes, and it allows for a comparison of results between this investigation and previous LCA results (Gallagher et al., 2015a, Arnøy and Modahl, 2013, Arnøy, 2013, AXPO, 2012, Hanafi and Riman, 2015, Pascale et al., 2011, Varun et al., 2008).

Taking into consideration data availability for the construction phase, including details on transportation, processing and raw materials, a 'cradle-to-gate' system boundary was selected. The analysis accounts for the product manufacturing and construction/installation of the MHP schemes investigated only. The burdens relating to the operational and disposal phases of the MHPs life cycle were not included in this study, as operational were difficult to quantify and considered to be negligible compared to construction-related impacts, i.e. 1\% (Vattenfall $A B, 2018$ ), while predicting future disposal 
was not deemed feasible as demolition of MHP are uncommon (Varun et al., 2008). The details of key processes considered are represented in Figure 1.

A contribution analysis was performed as part of the LCIA to quantify the primary contributions to the environmental burdens associated with the construction of the MHP projects. It allows for an exploration of opportunities to mitigate embodied environmental impacts in the construction of future MHP projects. Furthermore, an uncertainty and sensitivity analysis was conducted to examine the robustness of LCA results.

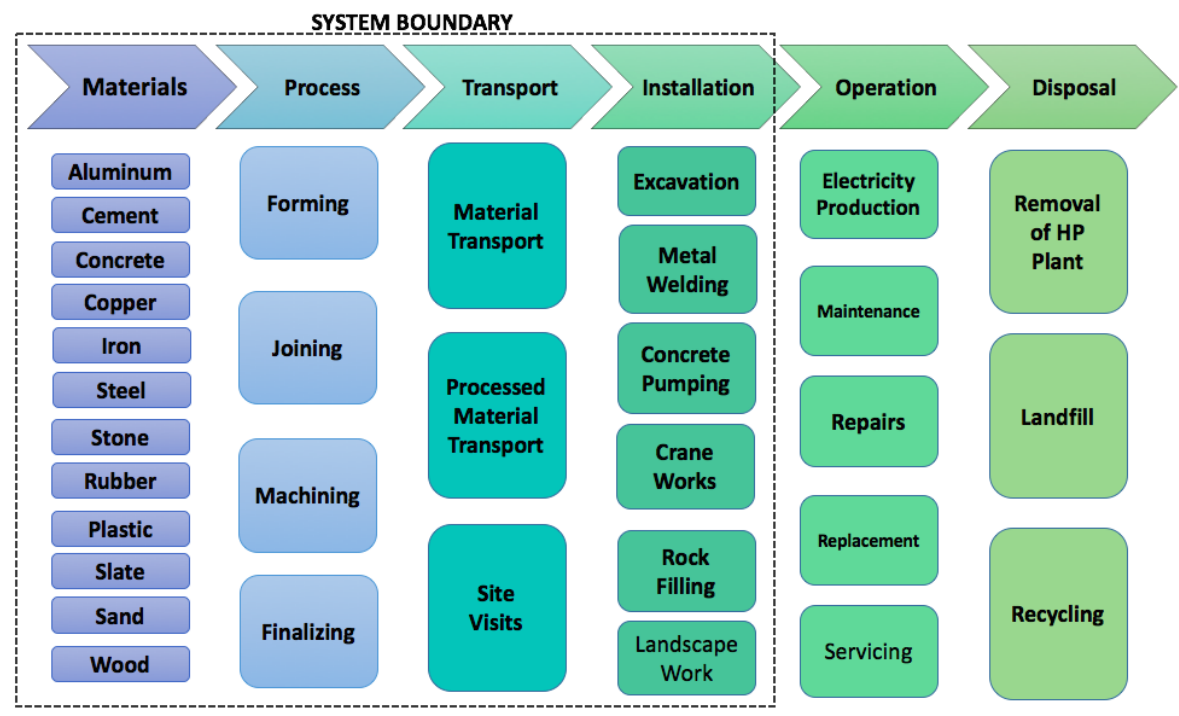

Figure 1. Process map and LCA system boundary for constructing the MHP schemes.

\subsubsection{Micro-hydropower case studies}

The eleven selected run-of-river MHP schemes were constructed in north Wales between 2014 and 2015, and have a design capacity ranging from 70 to $100 \mathrm{~kW}$. The steep mountainous terrain and high rainfall (Figure S1 in the Supplementary Information (SI)) with many small rivers and streams make the region an attractive location to develop low (>30 m), medium (30-60 m) and high ( $>60 \mathrm{~m}$ ) head MHP schemes. The location of the MHP plants investigated are predominantly within Snowdonia National Park in Wales (Figure 2).

Based on monthly precipitation measurements 2008-2017, average spring ( $83 \pm 38 \mathrm{~mm}$ ) and summer (113 $\pm 46 \mathrm{~mm}$ ) precipitation in Wales was much lower than autumn $(137 \pm 62 \mathrm{~mm})$ and winter $(170 \pm 71 \mathrm{~mm})$ precipitation (Met Office, 2018). As water flow in the river is dependent on precipitation, the output of electricity at the selected MHP sites varied throughout the year and, on average, generating more electricity in the autumn and winter months. 
All the MHP schemes shared the same components: weir, intake, penstock, powerhouse including turbine and generator and tailrace. The details of each MHP installation investigated are included in Tables S1-S3 in the SI.

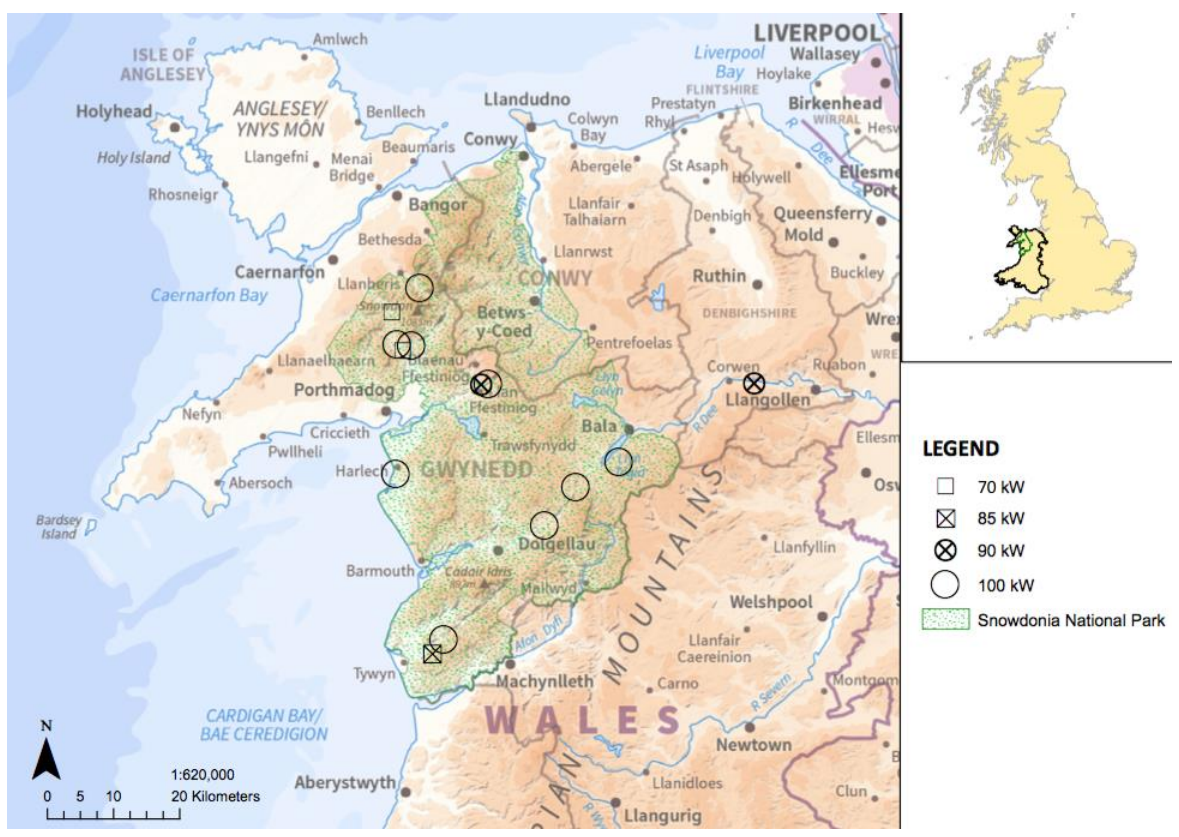

Figure 2. Locations of the eleven micro-hydropower schemes investigated in this LCA study.

\subsection{Life cycle inventory $(\mathrm{LCl})$ data collection}

Primary data related to the MHP installations were collected from the following sources for each site:

- Approved drawings - general manufacturing system layout drawings, including electricity generation plan;

- Detailed drawings - included further details of intake, penstock and power house structures;

- Bills of quantities and actual data - a detailed list that contained all the materials used in the design process. Construction and manufacturing processes (e.g. excavation works, welding galvanizing steels, etc.), transportation and logistics for components were also provided by contractors, suppliers and project managers.

The detailed drawings and supporting bill of quantities provided the most important data, such as quantity of raw materials, details of construction and manufacturing processes, energy consumption, and transportation. This was important to ensure the accuracy of the LCA results, as Gallagher et al. (2015b) highlighted the importance of including multiple small component contributions to the overall footprint of MHP electricity. In general, the life cycle inventories for raw materials used were expressed in $\mathrm{kg}$ or $\mathrm{m}^{3}$, 
while electricity and fuel consumptions were represented as kWh and MJ, respectively. The list of major items and processes considered for each HP scheme during LCA procedure is provided in Tables S2 and S4-S8 in SI.

A small number of data were not available for some sites, therefore as the same consultants designed each scheme, the specifications were replicated for some components from other schemes with similar characteristics, e.g. data for a single Turgo turbine was replicated for all schemes, whilst excavation works, sensing cable, and fixings data were replicated for some sites with missing data. The LCl also used some secondary data sources such as the Ecoinvent v.3.2 database (Ecoinvent, 2015) accessed via the opensource software OpenLCA (Open LCA, 2017).

\subsection{Impact categories and indicators}

Prior to quantifying the potential environmental impacts of the MHP schemes, LCIA impact categories were selected. The CML-IA baseline method is an appropriate method to assess the key environmental impacts associated with MHP installations (CML, 2016). The following five impact categories were chosen from the CML-IA baseline method: global warming potential (GWP); acidification potential (AP); human toxicity potential (HTP); abiotic resource depletion (ARDP); fossil resource depletion potential (FRDP) (CML, 2010). These impact categories map on to three broad areas of environmental impact - ecosystem damage, human health and resource scarcity. Previous LCA studies of micro-hydropower have used this CML-IA baseline method, and considered similar impact categories to those selected for this study (AXPO, 2012, Gallagher et al., 2015a, Hanafi and Riman, 2015, Suwanit and Gheewala, 2011).

As sustainable design is a key consideration and a technical focus of this study, and LCA has the scope to inform more environmentally sustainable design of MHP and other RE technologies, this study focused on the embodied construction and manufacturing burdens of these MHP installations. As such, the boundary conditions of this investigation and the impact categories selected reflect a focus on selecting burdens that are representative of ecosystem damage, human health and resource scarcity in different ways. However, the underlying focus is how the LCA results can identify hotspots and inform better design, and the selection of the five impact categories are considered to adequately capture this consideration. The use of these five impact categories to accurately capture major contributors to ecosystem damage, human health and resource scarcity was previously demonstrated by (Gallagher et al., 2015b).

\subsection{Assumptions and limitations}


Due to limited data and data quality constraints involved in the LCI phase for some MHP case studies, several assumptions were made to facilitate the LCA study (see Table S3 in SI.) based on consultation with MHP contractors, designers and developers. These included defining the specifications of the control panel and generator for each site, as data were limited for these components of the projects. In other cases, the impact category data for the listed items were obtained from Ecoinvent v.3.2 (Ecoinvent, 2015).

The approach to this LCA study is from a technical engineering perspective to examine burden hotspots which can support opportunities for reducing associated environmental impacts in the future. By considering five impact categories, in addition to a predominant focus on quantifying embodied construction and manufacturing impacts related to MHP projects, there is clear omission of associated ecological impacts of construction on e.g. local flora and fauna in the river. Distinct site-specific characteristics present a challenge in quantifying the future impacts of constructing these MHP projects, therefore the boundary conditions of this study omit this aspect from the operational life cycle results.

\subsection{Interpretation and analyses of LCA results}

The results for the eleven MHP project were compared for each of the five impact categories to identify any similarities and differences in terms of the main material and associated burden contributors between the schemes. Graphical representations of environmental impacts across five major MHP design and construction categories (Intake, Penstock, Powerhouse, Mechanical \& Electrical (M\&E), and Site visits) for individual schemes were prepared to determine which scheme sections made the greatest contributions to environmental burdens. In a similar manner, results were broken down according to the main materials used (categorized as Concrete \& Aggregate, Metals, Plastics, Processes, Transport, Wood and Others). This contribution analysis informed exploration of potential improvements for MHP designs to mitigate embodied environmental impacts in the construction of MHP plants.

A normalization of the impact category results was undertaken to compare environmental performance of each MHP scheme across impact categories. The reference value used for the normalization step was based on the average annual per capita environmental impact in the EU-25, obtained from the CML characterization database (CML, 2010).

\subsubsection{Uncertainty and sensitivity analysis}

Sensitivity analyses were conducted as per scenarios listed in Table 1 to evaluate the effect of the environmental impacts of the MHP installations. The sensitivity analysis examined the robustness of the LCA results, quantifying the margin of error that may occur in deviations in the environmental impacts for 
each scenario. Scenarios 1-3 consider possible uncertainties in the results by assessing the impact of under- or over-estimations in the data obtained for material, transport or excavation demands. Scenarios 4 and 5 present sensitivity and mitigation related impacts when modifications in the design and construction these MHP installations.

Table 1. Uncertainty and sensitivity analysis scenarios considered in the life cycle impacts associated with the construction of micro-hydropower installations.

\begin{tabular}{ll}
\hline \multicolumn{1}{c}{ Scenario } & \multicolumn{1}{c}{ Reason for each scenario } \\
\hline $\begin{array}{l}\text { 1. 10\% variation in raw material } \\
\text { quantities }\end{array}$ & $\begin{array}{l}\text { To account for possible variances in quantities of raw materials (e.g. } \\
\text { concrete, steel, etc.) required for MHP construction. }\end{array}$ \\
$\begin{array}{l}\text { 2. } 50 \% \text { variation to distance of } \\
\text { materials to be transported to site }\end{array}$ & $\begin{array}{l}\text { To determine the impact of additional or reduced transportation } \\
\text { requirements for materials and components for each MHP installation }\end{array}$ \\
$\begin{array}{ll}\text { 3. 100\% variation in rock excavation } \\
\text { Consider the possibility of doubling or halving the required rock } \\
\text { excavation due to different riverbed characteristics }\end{array}$ \\
$\begin{array}{ll}\text { 4. No excavation required for } \\
\text { penstock (placed above-ground) }\end{array}$ & $\begin{array}{l}\text { Account for a reduction in excavation requirements by installing the } \\
\text { penstock above ground } \\
\text { e.g. wood frame for concrete }\end{array}$ \\
\hline
\end{tabular}

\section{RESULTS \& DISCUSSION}

\subsection{Contribution analysis}

An analysis was conducted to quantify the contribution of each material or process towards each impact category, and the results presented per kWh of electricity generated for each MHP installation, separated into material contributions, are displayed in Figure 3.

Figure 3 illustrates how plastics, metals and concrete production (embodied burdens) are the primary environmental burden contributors for these MHP installations, while transport, and construction and manufacturing processes contribute to a lesser degree. The mean and standard deviation burdens across the MHP projects were as follows: $7.19 \pm 3.09 \mathrm{~g} \mathrm{CO}_{2}$ eq. for GWP; $0.031 \pm 0.010 \mathrm{~g} \mathrm{SO}_{2}$ eq. for AP; $13.5 \pm$ 8.3 g 1,4-DCB eq. for HTP; 7.1E-05 $\pm 3.1 \mathrm{E}-05 \mathrm{~g}$ Sb eq. for ARDP; and $0.136 \pm 0.049 \mathrm{MJ}$ for FRDP. Based on previous LCA investigations, results were comparable for GWP for three MHP installations constructed in India and assessed in Varun et al. (2008), and for each of the five impact categories for three MHP projects developed in the UK examined by Gallagher et al. (2015a).

The contribution of concrete and aggregates towards the construction of the MHP installations examined in this study accounted for $25-44 \%, 7-27 \%$ and $7-17 \%$ of the GWP, AP and FRDP burdens, respectively. Concrete and aggregate materials were mainly used for constructing the intake weir and the 
powerhouse, and these materials represent the second or third largest contributor across all categories, although they represent less than 5\% of HTP and ARDP burdens on average.

Metals were predominantly responsible for the largest share of ARDP (79-98\%), HTP (86-98\%) and AP (29-67\%) burdens, while also making a large contribution to GWP (9-23\%) and FRDP (7-17\%) categories. Steel and copper were the two metals most commonly used in each of the MHP installations. They were required for some of the pipe connections and the electrical and mechanical equipment i.e. turbine, generator and electrical connections (five-core copper steel wired armoured cable). The HTP and ARDP impacts associated with Scheme 5 were significantly higher than other MHP installations due to a required upgrade to three-phase HV cable. Since copper is one of the main contributors towards HTP and ARDP burdens, this cable upgrade meant that Scheme 5 had comparatively high total HTP and ARDP burdens (Fig. 3).

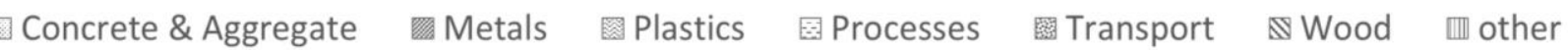

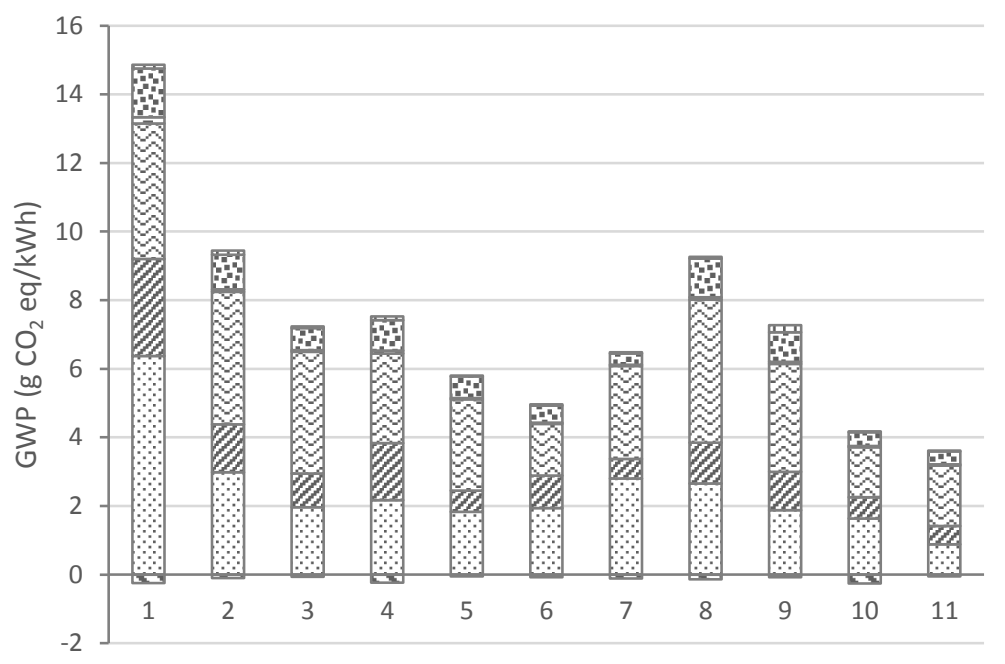

(a)

Site No. 


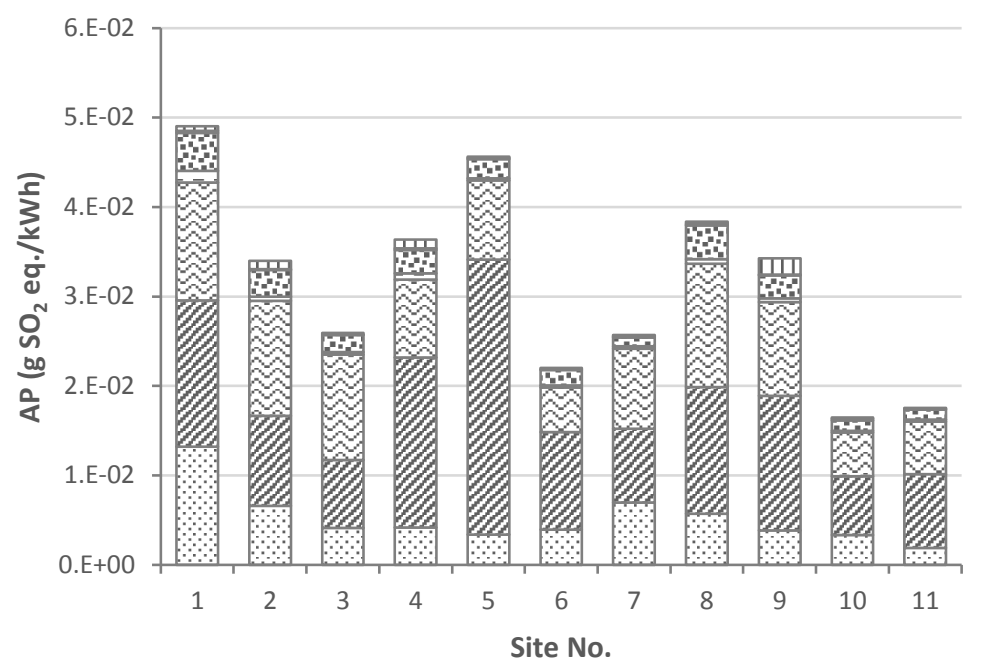

(b)

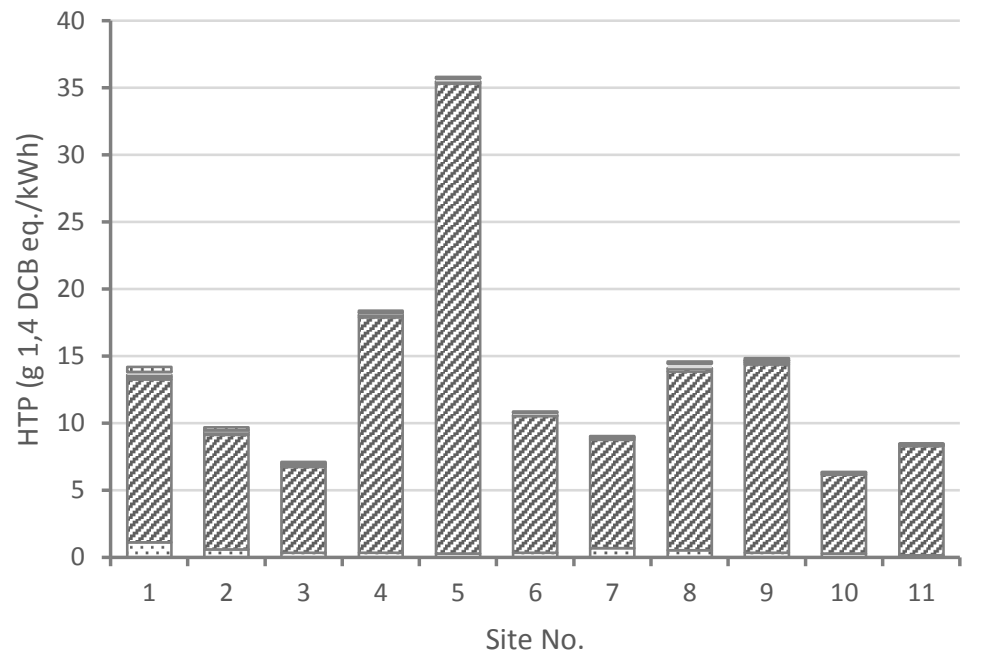

(c)

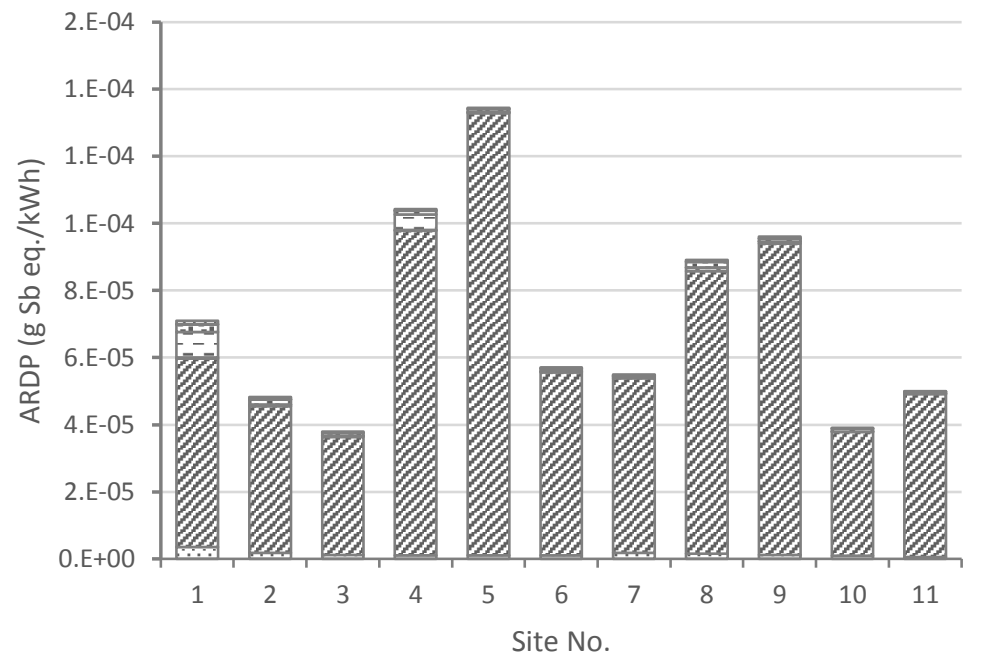

(d) 


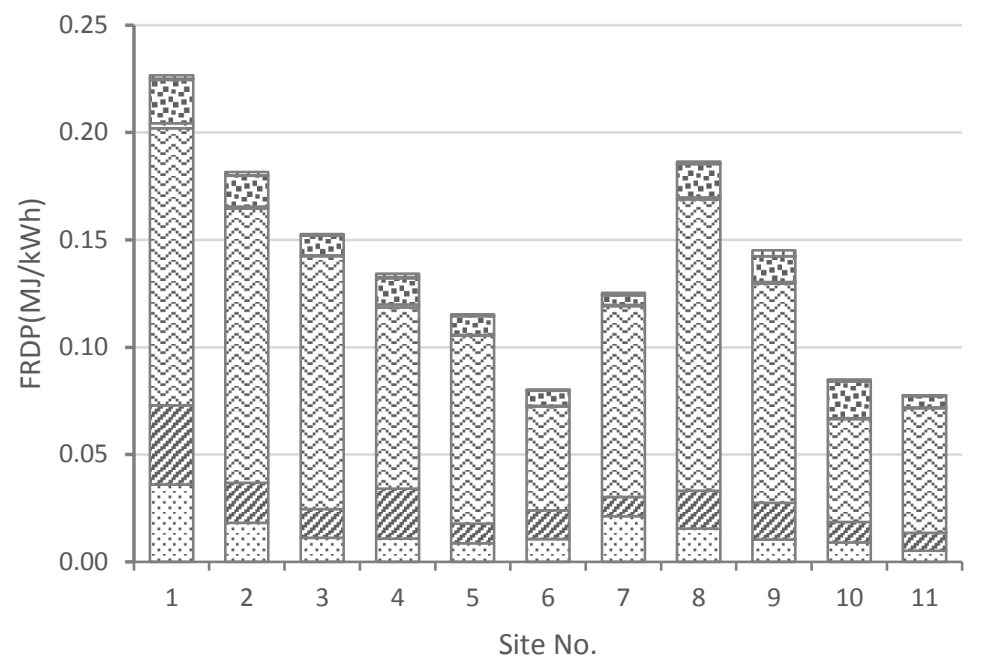

(e)

Figure 3. Material and process contributions towards environmental impacts associated with the construction of the eleven MHP schemes for (a) GWP, (b) AP, (c) HTP, (d) ARDP and (e) FRDP (results are expressed per kWh generated over projected 50-year lifespan).

High contributions for the FRDP, GWP and AP burdens were attributed to plastics used in the MHP installations, equating to $56-77 \%, 27-49 \%$ and $19-45 \%$ of these burdens, respectively. This was due to large quantities of high-density polyethylene plastic pipework required for each project.

Transport burdens were evident for FRDP, GWP and AP, accounting for $4-20 \%, 5-12 \%$ and $4-10 \%$ of these impact categories, respectively. A notable $11 \%$ of the environmental impact was associated with construction and manufacturing processes for all components for a single MHP installation (Scheme 1). The cumulative environmental contributions of other materials, such as glass, were negligible for all impact categories. As wood is considered as a material that sequesters carbon over its lifecycle in the LCA database, it presented unique results for the GWP burden by offsetting an average $2 \%$ of GWP burdens for the MHP installations. Wood contributed less than $0.5 \%$, on average, towards other impact categories.

Schemes 1 and 5 presented distinctly higher environmental impacts than all other sites. For Scheme No.1, the higher burdens were evident for all materials and processes in this MHP installation, across all impact categories, with large contributions related to construction and manufacturing processes, and concrete and aggregate. This was due to the MHP installation at Scheme No.1 requiring a more robust turbine design and larger generator due to its low head characteristics. As previously stated for Scheme No.5, the requirement for a large quantity of additional copper for the upgrade of nearly 3-kilometer of a single-phase HV power connection to a three-phase HV cable led to high AP and ARDP impacts. These distinct results for Schemes No.1 \& No.5 demonstrate the unique characteristics of some MHP installations which presents challenges for generalising on the environmental performance of MHP 
electricity, and for undertaking accurate LCA of specific projects with limited data.

\subsection{Uncertainty and sensitivity analysis}

Table 2 presents the uncertainty and sensitivity analysis results which consider the impact of inaccuracies in material quantities consumed, manufacturing and transport variations, and replacement of materials with reduced environmental impacts. It summarises the findings related to each scenario investigated, as shown in Table S9 in the SI. The first three (Scenarios 1, 2 and 3) account for the potential underestimation of the data obtained (uncertainty analyses). Scenarios 4 and 5 consider methods to reduce the overall impact associated with constructing the MHP case studies (sensitivity and mitigation analyses).

Table 2. Summary of impact category results for uncertainty and sensitivity analysis scenarios with the life cycle impacts associated with the construction of the MHP installations.

\begin{tabular}{|c|c|c|c|c|c|}
\hline \multirow{2}{*}{$\begin{array}{l}\text { Uncertainty and sensitivity } \\
\text { analysis scenarios }\end{array}$} & \multicolumn{5}{|c|}{ Percentage difference for each impact category } \\
\hline & GWP & AP & HTP & ARDP & FRDP \\
\hline $\begin{array}{l}\text { Scenario 1: } 10 \% \text { difference in } \\
\text { material quantities }\end{array}$ & $\pm 4.6-6.3 \%$ & $\pm 4.2-7.3 \%$ & $\pm 2.4-7.9 \%$ & $\pm 1.1-6.7 \%$ & $\pm 5.7-7.7 \%$ \\
\hline $\begin{array}{l}\text { Scenario 2: } 50 \% \text { difference in } \\
\text { distance of material } \\
\text { transportation to site }\end{array}$ & $\pm 2.5-5.8 \%$ & $\pm 1.8-4.7 \%$ & $\pm 0.2-1.2 \%$ & $\pm 0.3-1.6 \%$ & $\pm 1.8-4.4 \%$ \\
\hline $\begin{array}{l}\text { Scenario } 3: 100 \% \text { difference in } \\
\text { rock excavation }\end{array}$ & $\pm 0.1-0.2 \%$ & $\pm 0.1-0.3 \%$ & $< \pm 0.1 \%$ & $< \pm 0.1 \%$ & $\pm 0.1 \%$ \\
\hline $\begin{array}{l}\text { Scenario 4: No excavation } \\
\text { required for penstock (placed } \\
\text { above-ground)* }\end{array}$ & $(0.3-0.9 \%)$ & $(0.3-1.2 \%)$ & $(<0.1 \%)$ & $(<0.1 \%)$ & $(0.2-0.8 \%)$ \\
\hline $\begin{array}{l}\text { Scenario 5: Alternative } \\
\text { powerhouse materials e.g. } \\
\text { wood frame for concrete* }\end{array}$ & $(6.3-12.2 \%)$ & $0.1-0.7 \%$ & $<0.1 \%$ & $<0.1 \%$ & $<0.1-0.3 \%$ \\
\hline
\end{tabular}

* Negative values are presented in brackets () and represent a reduction in the environmental impact of the MHP projects.

A 10\% difference in the consumption of raw materials in the project, as considered in Scenario 1, would relate to the greatest change in the results for each MHP installation across all environmental impact categories examined, leading to a variation of up to $7.7 \%$ in total burden across impact categories.

In comparison, Scenarios 2 and 3 considered a 50\% variance in material transport and a $100 \%$ variance in rock excavation respectively. For Scenario 2, the $50 \%$ variance in transportation impacts could affect the results by between $\pm 1.8 \%$ and $\pm 5.8 \%$ for GWP, AP and FRDP categories and a lesser $\pm 0.2-1.6 \%$ for HTP and ARDP. Doubling or halving the total quantity of rock excavation in the project, as considered in Scenario 3 , was shown to generate a $\pm 0.2 \%$ variation in the environmental burdens for the MHP projects. 
Scenarios 4 and 5 were presented as methods to reduce the overall environmental impacts of the MHP installations. Scenario 4 considered the installation of the penstock and all pipework above ground, thus negating the requirements for any soil or rock excavation. However, a covered penstock pipe protects against frost damage, mechanical damage and UV degradation of the pipes (CETC, 2004, PPI, 2008). Reforesting around an exposed penstock is an alternative method to protect the infrastructure (Ramos and de Almeida, 1999), and would concurrently help offset GHG emissions.

This provided marginal reductions in the environmental impact of the projects, with a maximum reduction for some MHP installations of $0.8-1.2 \%$ for GWP, AP and FRDP impacts, while reductions less than $0.1 \%$ were noted for HTP and ARDP. In contrast, the consideration for replacing the concrete powerhouse with a wood frame structure in Scenario 5 reduced the GWP burden of each project by 6.312.2\%. However, it presented marginal increases of up to $0.7 \%$ in the overall burden for all other impact categories for each scheme. This result relates to wood acting as a carbon sink, thus the replacement of concrete block walls with hardwood timber frame and cladding offers a reduction in the GWP burden for these projects. As the powerhouse at Scheme No.3 used local stone as opposed to other schemes which used concrete blocks, the selection of local materials, either wood or stone, is important to consider and can reduce transport and manufacturing burdens of these projects.

High head MHP projects also presented a greater sensitivity in Scenario 2 as material transport to the weir location and the installation of pipework was more challenging. Despite the low sensitivity to rock excavation in Scenario 3, high-head MHP installations were the most sensitive to change as the river bed at higher head schemes have a more rock-strewn environment with high gradients. Overall, the low and high head MHP scheme were the least and most sensitive to changes in values of input data, respectively.

\subsection{Normalized results of MHP case studies}

To observe the overall environmental performance of the MHP case studies, each impact category was normalized with respect to European reference values obtained from CML characterization database (CML, 2010).

\subsubsection{Size of MHP installation}

Table 3 presents the normalized results for the four different sizes of MHP installations and for all five impact categories.

Table 3. Normalized impact category results presented as mean and standard deviation of installed capacity for each 
size classification of MHP installation during the construction phase.

\begin{tabular}{|c|c|c|c|c|c|c|c|}
\hline \multicolumn{3}{|c|}{ Installation } & \multicolumn{5}{|c|}{ Environmental impact category } \\
\hline Size & $\begin{array}{c}\text { No. of } \\
\text { installations }\end{array}$ & Value & GWP & AP & HTP & ARDP & FRDP \\
\hline \multirow[t]{2}{*}{$70 \mathrm{~kW}$} & 1 & Mean & $6.66 \mathrm{E}-07$ & $5.67 \mathrm{E}-07$ & 8.87E-07 & $5.28 \mathrm{E}-07$ & $2.14 \mathrm{E}-06$ \\
\hline & & St Dev & - & - & - & - & - \\
\hline \multirow[t]{2}{*}{$85 \mathrm{~kW}$} & 1 & Mean & $6.75 \mathrm{E}-07$ & $6.01 \mathrm{E}-07$ & $1.10 \mathrm{E}-06$ & $5.73 \mathrm{E}-07$ & $1.98 \mathrm{E}-06$ \\
\hline & & St Dev & - & - & - & - & - \\
\hline \multirow[t]{2}{*}{$90 \mathrm{~kW}$} & 2 & Mean & $1.10 \mathrm{E}-06$ & $7.23 \mathrm{E}-07$ & $8.60 \mathrm{E}-07$ & 4.40E-07 & 3.05E-06 \\
\hline & & St Dev & $\pm 3.59 \mathrm{E}-07$ & $\pm 1.25 \mathrm{E}-07$ & $\pm 1.82 \mathrm{E}-08$ & $\pm 7.01 \mathrm{E}-08$ & $\pm 4.19 \mathrm{E}-07$ \\
\hline \multirow[t]{2}{*}{$100 \mathrm{~kW}$} & 7 & Mean & $5.42 \mathrm{E}-07$ & $4.43 E-07$ & $7.46 \mathrm{E}-07$ & 3.31E-07 & $1.70 \mathrm{E}-06$ \\
\hline & & St Dev & $\pm 1.86 \mathrm{E}-07$ & $\pm 1.69 \mathrm{E}-07$ & $\pm 6.21 \mathrm{E}-07$ & $\pm 1.84 \mathrm{E}-07$ & $\pm 6.13 \mathrm{E}-07$ \\
\hline
\end{tabular}

The results suggest a relative reduction in the environmental burdens results for larger size MHP installations, and moreover, a greater confidence in the $100 \mathrm{~kW}$ MHP projects results can be attained as seven of the eleven MHP schemes were of this size of installation. However, it was evident from the 85 kW (Scheme No.5) and $90 \mathrm{~kW}$ (Schemes No.1 and 9) installations that site-specific characteristics can influence variation of the environmental impacts of a MHP project, for example selecting boundary conditions which incorporates the inclusion of a grid connection based on availability presented significant increases in the ARDP burden for Scheme No.5. In addition, indications site characteristics, such as a low head turbine design which requires a more robust MHP turbine can increase raw material demands. As such two schemes with the same design capacity for generation, and with the same functional unit, may generate distinct results as the boundary conditions of the MHP and design characteristics affect the final results.

\subsubsection{Environmental impacts vs. head \& flow variations}

The results in Figure 4 compare the fit equations, presented as logarithmic trendlines, for the environmental impacts versus the head/flow ratio of all installations compared to the grouping of sites that excludes MHP Schemes No.7, 8 \& 9. These results aim to help determine whether equations can be generated to estimate the burdens associated with a MHP project based on known head and flow characteristics at a site. For three of the five impact categories considered - GWP, AP and FRDP - the fit of the equations improved when the three schemes were removed as outliers. The capacity factors of Schemes No. 7-9 were low in relation to their high head characteristics. The specific burden categories 
where improved fit for the equations were observed appeared to relate to plastic pipe demand for projects; outlier schemes appeared to have atypical pipe requirements due to distinct capacity factors and head and flow parameters. There was no evident relationship between HTP and ARDP burdens and head to flow ratio across the MHP projects.

The turbine selection for low head and high flow schemes requires a more robust installation i.e. larger crossflow turbine with greater material demands for installation, which can lead to larger GWP and FRDP burdens. The results demonstrate how head and flow characteristics alone do not allow for an accurate calculation of the environmental impact of any MHP installation. In particular, it does not appear feasible to accurately estimate results for a large number of different burden categories using simple equations related to head and flow, based on results from a respectable subset of similar capacity MHP installations in this study.

(a)

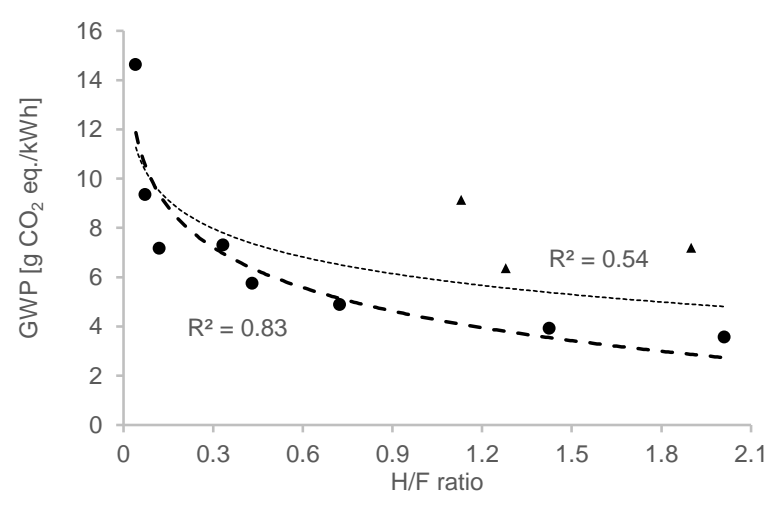

(b)

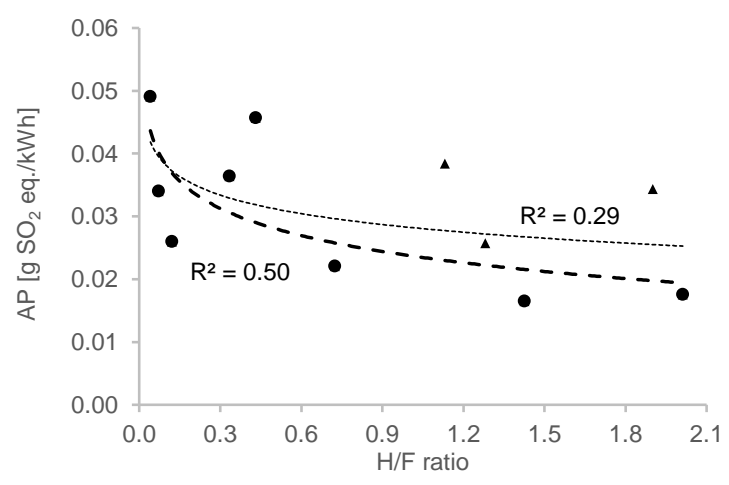

(c)

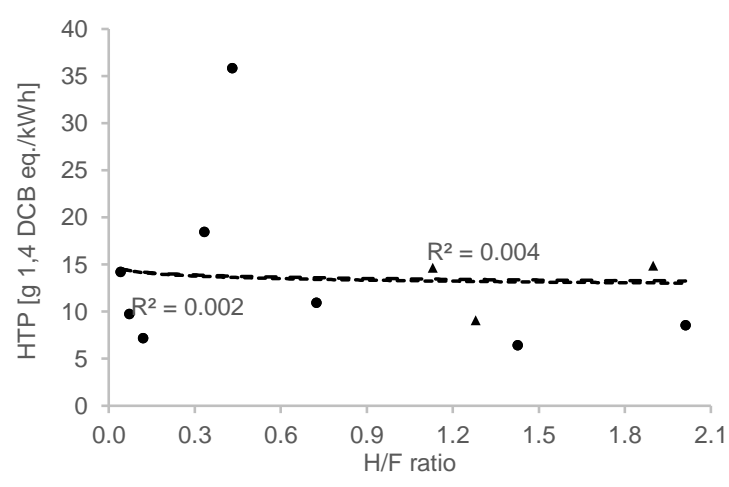



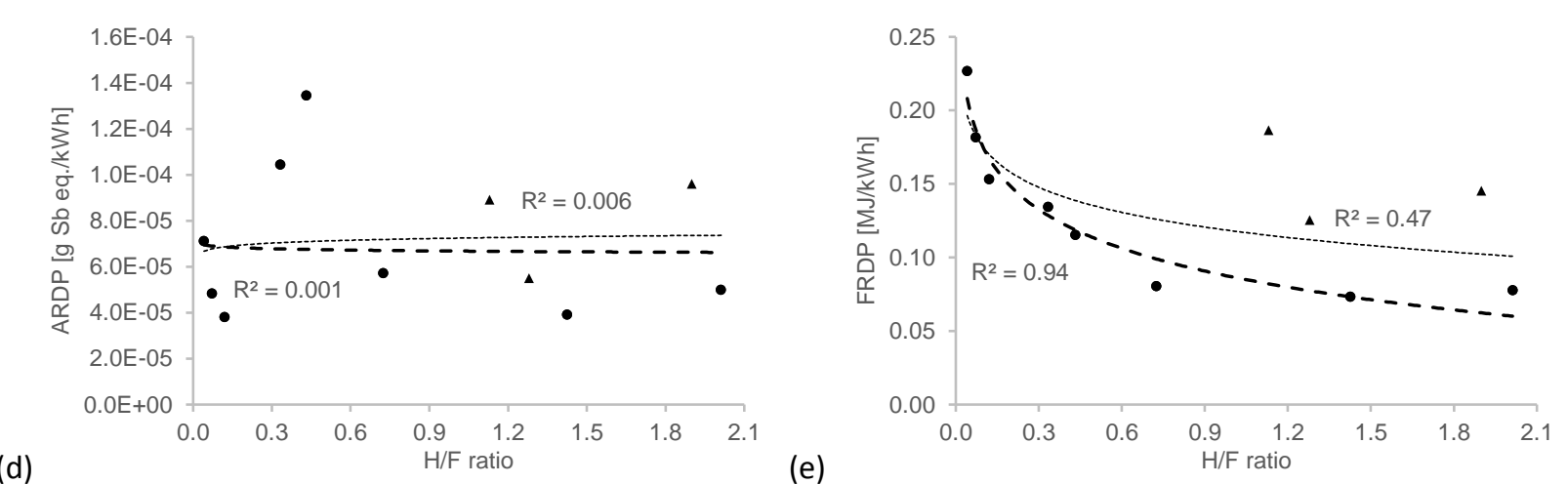

Figure 4. Environmental impacts vs. head/flow ratio in the construction-related burdens of each run-of-river MHP installation for all sites versus subset of sites (excluding sites No.7, 8 \& 9) for impact categories (a) GWP, (b) AP, (c) HTP, (d) ARDP and (e) FRDP.

\section{CONCLUSIONS}

The LCA results demonstrate material hotspot contributors such as production of concrete and aggregates, metals and plastics to the embodied environmental burdens in the construction of MHP installations. Changes in material demands in constructing MHP installations can therefore significantly impact upon the overall project burdens. This was evident in one low-head installation that required significantly larger quantities of materials, and this translated as the scheme with the highest GWP, AP and FRDP burdens. The use of alternative materials in construction has potential to reduce environmental impacts of MHP energy e.g. substitution of concrete powerhouse structures with wooden structures can notably reduce GWP burden. One MHP installation presented comparatively high HTP and ARDP burdens due to the requirement for a 3-kilometre grid connection upgrade for exporting electricity. This finding suggests that strategically positioning the generator during the planning process can reduce the overall environmental impacts in constructing a MHP installation.

The environmental impacts of the MHP case studies demonstrated how the construction of larger MHP projects had a lower environmental performance. Variations in results were noted to be linked to different construction methods and the selection of turbines to meet the requirements for each scheme. These differences were due to high-head schemes having a higher generation capacity whilst requiring similar sized intakes and pipes, and small turbines. This translated as reduced demands for construction materials and site excavation works per kWh of electricity. Despite the relationship between the environmental impacts of a MHP project and the size of the installation, there is no simple method of quantifying the associated burdens for all impact categories.

The LCA results from this study demonstrate the clear distinctions in the embodied burden results associated with the construction of MHP projects that are of a similar size. This reinforces the need for 
independent LCA case studies to be undertaken for renewable energy projects. Such studies can inform improved design and construction opportunities, with respect to material selection and site design characteristics, which can potentially enhance the environmental performance of these installations in line with circular economy principles.

\section{ACKNOWLEDGEMENTS}

This research has been supported in part by European Regional Development Fund through the Ireland Wales Cooperation programme (D̂̂r Uisce project) and through the Interreg Atlantic Area programme (REDAWN project).

\section{REFERENCES}

Arnøy, S. 2013. Hydroelectricity from Trollheim power station. Environmental Product Declaration ISO 14025. OSLO: Østfoldforskning AS.

Arnøy, S. \& Modahl, I. S. 2013. Life Cycle Data for Hydroelectric Generation at Embretsfoss 4(E4) Power Station: Background Data for Life Cycle Assessment (LCA) and Environmental Product Declaration (EPD) Kråkerøy, Norway: Ostfold Research.

Asdrubali, F., Baldinelli, G., D’Alessandro, F. \& Scrucca, F. 2015. Life cycle assessment of electricity production from renewable energies: Review and results harmonization. Renewable and Sustainable Energy Reviews, 42, 1113-1122.

AXPO 2012. Environmental Product Declaration: Wildegg-Brugg Run-of-River Power Plant. Baden, Switzerland: Axpo AG.

Bakken, T. H., Modahl, I. S., Engeland, K., Raadal, H. L. \& Arnøy, S. 2016. The life-cycle water footprint of two hydropower projects in Norway. Journal of Cleaner Production, 113, 241-250.

Bódis, K., Monforti, F. \& Szabó, S. 2014. Could Europe have more mini hydro sites? A suitability analysis based on continentally harmonized geographical and hydrological data. Renewable and Sustainable Energy Reviews, 37, 794-808.

CETC 2004. Micro-Hydropower Systems: A Buyer's Guide, a Publication of Hydraulic Energy Program. Renewable Energy Technology Program. Canada: CANMET Energy Technology Centre.

CML 2010. Characterisation Factors database available online from Institute of Environmental Sciences (CML). Universiteit Leiden, Leiden, 2010.

CML 2016. CML-IA Characterisation Factors. 5 September 2016 ed.: Universiteit Leiden, Leiden.

Coelho, C. D., da Silva, D. D., Sediyama, G. C., Moreira, M. C., Pereira, S. B. \& Lana, Â. M. Q. 2017. Comparison of the water footprint of two hydropower plants in the Tocantins River Basin of Brazil. Journal of Cleaner Production, 153, 164-175.

DECC 2013. UK Renewable Energy Roadmap Update 2013. Department of Energy \& Climate Change.

Donnelly, C. R., Carias, A., Morgenroth, M., Ali, M., Bridgeman, A. \& Wood, N. 2010. An assessment of the life cycle costs and GHG emissions for alternative generation technologies. World Energy Congress. Montréal, Canada.

Ecoinvent 2015. Ecoinvent database version 3.2. In: SIMAPRO, A. V. (ed.).

Gallagher, J., Basu, B., Browne, M., Kenna, A., McCormack, S. J., Pilla, F. \& Styles, D. 2018a. Adapting StandAlone Renewable Energy Technologies for the Circular Economy through Eco-Design and Recycling. Journal of Industrial Ecology. 
Gallagher, J., Coughlan, P., Williams, A. P. \& McNabola, A. 2018b. Innovating for low-carbon energy through hydropower: Enabling a conservation charity's transition to a low-carbon community. Creativity and Innovation Management, 27, 375-386.

Gallagher, J., Styles, D., McNabola, A. \& Williams, A. P. 2015a. Current and future environmental balance of small-scale run-of-river hydropower. Environ Sci Technol, 40, 6344-6351.

Gallagher, J., Styles, D., McNabola, A. \& Williams, A. P. 2015b. Inventory compilation for renewable energy systems: the pitfalls of materiality thresholds and priority impact categories using hydropower case studies. The International Journal of Life Cycle Assessment, 20, 1701-1707.

Gallagher, J., Styles, D., McNabola, A. \& Williams, A. P. 2015c. Making green technology greener: Achieving a balance between carbon and resource savings through ecodesign in hydropower systems. Resources, Conservation and Recycling, 105, Part A, 11-17.

Hanafi, J. \& Riman, A. 2015. Life Cycle Assessment of a Mini Hydro Power Plant in Indonesia: A Case Study in Karai River. Procedia CIRP, 29, 444-449.

IHA 2017. 2017 Key Trends in Hydropower. International Hydropower Association.

IRENA 2012. Renewable Energy Technologies: Cost Analysis Series. International Renewable Energy Agency.

IRENA 2016. Roadmap for a Renewable Energy Future. 2016 Edition ed.: International Renewable Energy Agency.

ISO 2006a. ISO 14040: environmental management - life cycle assessment - principles and framework. ISO, Geneva.

ISO 2006b. ISO 14044: environmental management - life cycle assessment - requirements and guidelines. ISO, Geneva.

Met Office 2018. UK Daily Rainfall. NCAS British Atmospheric Data Centre: Data Part of the Met Office Integrated Data Archive System (MIDAS).

Open LCA 2017. OpenLCA software. In: GREENDELTA (ed.).

Pascale, A., Urmee, T. \& Moore, A. 2011. Life cycle assessment of a community hydroelectric power system in rural Thailand. Renewable Energy, 36, 2799-2808.

Pehnt, M. 2006. Dynamic life cycle assessment (LCA) of renewable energy technologies. Renewable Energy, 31, 55-71.

PPI 2008. Above-Ground Applications for PE Pipe. Handbook of Polyethylene (PE) Pipe. The Plastics Pipe Institute, Inc.

Premalatha, M., Tabassum, A., Abbasi, T. \& Abbasi, S. A. 2014. A critical view on the eco-friendliness of small hydroelectric installations. Science of The Total Environment, 481, 638-643.

Ramos, H. \& de Almeida, A. B. 1999. Small Hydropower Schemes as an Important Renewable Energy Resource. Publicação com Referee Internacional. Hidroenergia 99, Vienna, Austria.

REN21 2016. Renewables 2016 Global Status Report. ISBN 78-3-9818107-0-7 ed. Paris.

Rule, B. M., Worth, Z. J. \& Boyle, C. A. 2009. Comparison of life cycle carbon dioxide emissions and embodied energy in four renewable electricity generation technologies in New Zealand. Environ Sci Technol, 43, 6406-13.

Suwanit, W. \& Gheewala, S. 2011. Life cycle assessment of mini-hydropower plants in Thailand. The International Journal of Life Cycle Assessment, 16, 849-858.

Tassinari, C. A., Bonilla, S. H., Agostinho, F., Almeida, C. M. V. B. \& Giannetti, B. F. 2016. Evaluation of two hydropower plants in Brazil: using emergy for exploring regional possibilities. Journal of Cleaner Production, 122, 78-86.

US DOE 2017. 2017 U.S. Energy and Employment Report. United States Department of Energy.

Varun, I., Bhat, K. \& Prakash, R. 2008. Life Cycle Analysis of Run-of River Small Hydro Power Plants in India. The Open Renewable Energy Journal, 1, 11-16.

Vattenfall AB 2018. Summer of Environmental Product Declaration (EPD) of Electricity from Vattenfall's 
Nordic Hydropower. Vattenfall AB.

Zhang, J. \& Xu, L. 2015. Embodied carbon budget accounting system for calculating carbon footprint of large hydropower project. Journal of Cleaner Production, 96, 444-451.

Zhang, L., Pang, M., Wang, C. \& Ulgiati, S. 2016. Environmental sustainability of small hydropower schemes in Tibet: An emergy-based comparative analysis. Journal of Cleaner Production, 135, 97-104.

Zhang, S., Pang, B. \& Zhang, Z. 2015. Carbon footprint analysis of two different types of hydropower schemes: comparing earth-rockfill dams and concrete gravity dams using hybrid life cycle assessment. Journal of Cleaner Production, 103, 854-862. 